\title{
GEOTOURISM POTENTIAL OF THE DRAWSKIE LAKE DISTRICT AS A SUPPORT FOR THE PLANNED GEOPARK NAMED POSTGLACIAL LAND OF THE DRAWA AND DĘBNICA RIVERS
}

\author{
Maria GórsKa-ZabielskA ${ }^{1}$, KatARZYNA KAMIEŃSKA ${ }^{2}$ \\ ${ }^{1}$ Institute of Geography, Jan Kochanowski University, Kielce, Poland \\ ${ }^{2}$ Maritime Institute in Gdańsk, Gdańsk, Poland
}

Manuscript received: August 3, 2015

Revised version: November 7, 2016

\begin{abstract}
GórSKA-ZabielsKa M., KAmieŃSKa K., 2017. Geotourism potential of the "Połczyn Switzerland" area as a support for the planned geopark named "Postglacial land of the Drawa and Dębnica rivers". Quaestiones Geographicae 36(1), Bogucki Wydawnictwo Naukowe, Poznań, pp. 15-31, 5 figs, 4 tables.

ABSTRACT. The geotourism potential of ten geosites, occurring within the Drawskie Lake District, north-western Poland, was evaluated to demonstrate the need for the establishment of a geopark named "Postglacial land of the Drawa and Dębnica rivers". Each site was investigated in respect of its scientific (geological and geomorphological), educational, economic, conservation, and added values. It has been found that two geosites, being also cultural heritage sites (Drahim Castle and Pottery Settlement in Sikory), have the greatest geotourism potential. Different aspects of inanimate nature are promoted in both geosites. Thanks to the existence of such objects there is a good chance for the successful development of geotourism, which is a tool for the sustainable socio-economic development of the region.
\end{abstract}

KEY wORDS: geodiversity, geotourism, geoconservation, geopark, Drawskie Lake District, north-western Poland

Corresponding author: Maria Górska-Zabielska,maria.gorska-zabielska@ujk.edu.pl

\section{Introduction}

Relief of the Middle Pomerania region, in north-western Poland, is characterized by high geodiversity. Most objects of inanimate nature have been formed by the Scandinavian ice sheet during its last stay in the discussed region, and by meltwater flowing from the ice-sheet front. Landforms representing other environments, e.g. spring, fluvial, and lacustrine, are also found in the area. Many of them are protected in the form of national park, landscaped park, documentary site, reserve or natural monument. However, some objects are waiting to be subjected to the conservator's supervision and put on the list of natural heritage objects of national importance, i.e. geoparks. For this purpose, the special objects of inanimate nature, called geosites, have to be subjected to inventory and evaluation procedures. Based on the results of these procedures, it will be established the network of geosites connected by educational paths and geotourist trails. Due to its educational, scientific, and tourist functions, such a network can become a tourist attraction and will favour the sustainable social and economic development of districts.

Inventory-evaluation procedure applied to inanimate nature objects is described in foreign literature. A detailed review of quantitative methods evaluating different values of abiotic objects 
in order to assess their usefulness for the development of geotourism has been recently published by Kubalíkova (2013). She described the methods used in Italy (Panizza 2001, Coratza and Giusti 2005), Spain (Serrano and Gonzalez-Trueba 2005, Bruschi and Cendrero 2005), Portugal (Pereira et al. 2007, Pereira and Pereira 2010), Greece (Zouros 2005, 2007), and Switzerland (Pralong 2005, Reynard et al. 2007). Based on the analysis of the criteria and categories used in the mentioned quantitative methods, Kubalikova (2013) proposed her own method of geosite evaluation for geotourism purposes. This method is used in our study to evaluate ten geosites in the planned geopark named "Postglacial land of the Drawa and Dębnica rivers".

The issues of geosite evaluation for geotourism purposes are also present in Polish literature, e.g. in the papers published by Borówka et al. (2008), Radwanek-Bąk and Laskowicz (2012), Kamieńska and Giemza (2014), and GórskaZabielska et al. (2015). Many publications are inventory studies, in which the main emphasis is placed on the presentation of the attractiveness of geomorphological and geological heritage of a region under study (among others Zgłobicki et al. 2007, Zgłobicki and Baran-Zgłobicka 2013, Górska-Zabielska and Zabielski 2016a, b). Various authors have tried to evaluate the inventoried natural resources, e.g. Kot (2006), Nita (2007), Borówka et al. (2008) Cedro et al. (2008), Duda et al. (2008), Dmytrowski and Kicińska (2011), Zbucki (2012), Radwanek-Bak and Laskowicz (2012). Some attempts have been also made to develop an objective method of geosite evaluation - Sołowiej (1992) published the analysis of scores grading method, while Kot and Leśniak (2006) studied the possibilities of developing the indicators or mathematical functions defining the level of connections and variability of geodiversity in neighbouring areas. There are also examples of methods for deriving a map of landform geodiversity in GIS environment and its application for indication of attractive touristic scenes in mountains areas (Zwoliński 2009, 2010, Zwoliński and Stachowiak 2012, Najwer and Zwoliński 2014a, b, 2015). Najwer and other (2016) demonstrate a new methodology for the assessment of the selected natural environment components in Polish lowland. Their analyses lead to visualize the landform geodiversity using the opportunities offered by the geoinformation environment. An attempt to develop a unified classification of geosites has been made in the Polish Geological Institute - National Research Institute in 2009 by the implementation of the Polish Central Register of Geosites (PIG-PIB 2016), which is constantly updated. Nowadays (January 2016) this register contains data of more than 3700 geosites, which have been evaluated in terms of their scientific, educational and geotourist values (Warowna et al. 2013).

The advantages of the above-mentioned papers are not only the attempts to develop an objective method of evaluation of geological resources but also the descriptions of attractive inanimate objects and the promotion of geotourism.

In this paper we describe ten geosites occurring along one of five geotourist paths planned in the area of future geopark. The described below values of these geosites can be used in environmental education, in teaching at various levels of education, and for scientific purposes. The values of geosites give also hope for the development of one of the qualified tourism types, namely geotourism. It is based on the exploration of geological objects, which can become a tourist attraction after their adaptation and making access to them. The advantage of geotourism is that it requires little financial outlays and can be organized almost everywhere. However, the basic condition is to prepare a professional information board explaining the origin and presenting the current state of a geosite.

\section{Purpose, scope and methods of research}

The purpose of this study is to indicate that ten selected geosites, located along one of five geotourist paths, have geotourism potential so the establishment of a geopark named "Postglacial land of the Drawa and Dębnica rivers" is needful.

Evaluation of geotourism potential was preceded by a procedure involving:

1. Making an inventory of inanimate nature objects in the study area. It was carried out during field work in 2010-2013, and the attention was mainly given to geological/geomorphological process/processes, which formed the studied natural resources. In the case of an object associated with human activity, the main 
Table 1. Categories, criteria, and scoring used in this study for the evaluation of geotourism potential of the "Połczyn Switzerland" area.

\begin{tabular}{|c|c|c|c|c|}
\hline \multirow{2}{*}{ Category } & \multirow{2}{*}{ Criterion } & \multicolumn{3}{|c|}{ Scores } \\
\hline & & 0 & 0.5 & 1 \\
\hline \multirow[t]{4}{*}{$\begin{array}{l}\text { Scientific } \\
\text { value }\end{array}$} & $\begin{array}{l}\text { integrity (object } \\
\text { forming insepara- } \\
\text { ble entirety) }\end{array}$ & $\begin{array}{l}\text { completely de- } \\
\text { stroyed }\end{array}$ & $\begin{array}{l}\text { destroyed but with still } \\
\text { visible abiotic features }\end{array}$ & not destroyed \\
\hline & $\begin{array}{l}\text { frequency (number } \\
\text { of similar sites) }\end{array}$ & $\begin{array}{l}\text { more than } 5 \\
\text { objects }\end{array}$ & $2-5$ objects & one object in the study area \\
\hline & $\begin{array}{l}\text { geodiversity (num- } \\
\text { ber of different fea- } \\
\text { tures or processes } \\
\text { visible in geosite) }\end{array}$ & $\begin{array}{l}\text { only } 1 \text { visible } \\
\text { feature/process }\end{array}$ & $\begin{array}{l}\text { 2-4 visible features/pro- } \\
\text { cesses }\end{array}$ & $\begin{array}{l}\text { more than } 5 \text { visible features/ } \\
\text { processes }\end{array}$ \\
\hline & $\begin{array}{l}\text { scientific knowl- } \\
\text { edge }\end{array}$ & $\begin{array}{l}\text { lack }=\text { not investi- } \\
\text { gated site }\end{array}$ & $\begin{array}{l}\text { scientific paper in national } \\
\text { journal }\end{array}$ & $\begin{array}{l}\text { extensive knowledge of the } \\
\text { site, published monography }\end{array}$ \\
\hline \multirow[t]{4}{*}{$\begin{array}{l}\text { Educational } \\
\text { value }\end{array}$} & $\begin{array}{l}\text { Representativeness } \\
\text { and visibility/ } \\
\text { clarity of features/ } \\
\text { processes }\end{array}$ & $\begin{array}{l}\text { weak represent- } \\
\text { ativeness/clar- } \\
\text { ity of form and } \\
\text { process }\end{array}$ & $\begin{array}{l}\text { medium representative- } \\
\text { ness, mainly for specialists }\end{array}$ & $\begin{array}{l}\text { high representativeness of } \\
\text { form and process, also for } \\
\text { amateurs }\end{array}$ \\
\hline & $\begin{array}{l}\text { quality of educa- } \\
\text { tional example, } \\
\text { educational useful- } \\
\text { ness }\end{array}$ & $\begin{array}{l}\text { weak example, } \\
\text { weak educational } \\
\text { usefulness of } \\
\text { form and process }\end{array}$ & $\begin{array}{l}\text { good example but of limit- } \\
\text { ed educational usefulness }\end{array}$ & $\begin{array}{l}\text { very good example with high } \\
\text { educational and geotourist } \\
\text { usefulness }\end{array}$ \\
\hline & $\begin{array}{l}\text { existing educational } \\
\text { products }\end{array}$ & lack & leaflets, maps, web pages & $\begin{array}{l}\text { information boards, informa- } \\
\text { tion next to the site }\end{array}$ \\
\hline & $\begin{array}{l}\text { existing forms of } \\
\text { use for educational } \\
\text { purposes (specialist } \\
\text { tour, guided tour) }\end{array}$ & $\begin{array}{l}\text { lack of education- } \\
\text { al use }\end{array}$ & $\begin{array}{l}\text { site is a part of specialist } \\
\text { tour (eg. for students, geo- } \\
\text { tourists) }\end{array}$ & $\begin{array}{l}\text { guided tour for the general } \\
\text { public }\end{array}$ \\
\hline \multirow[t]{3}{*}{$\begin{array}{l}\text { Economic } \\
\text { value }\end{array}$} & accessibility & $\begin{array}{l}\text { more than } 1000 \mathrm{~m} \\
\text { from the car park }\end{array}$ & $\begin{array}{l}\text { less than } 1000 \mathrm{~m} \text { from the } \\
\text { car park }\end{array}$ & $\begin{array}{l}\text { less than } 1000 \mathrm{~m} \text { from the pub- } \\
\text { lic transport stop }\end{array}$ \\
\hline & $\begin{array}{l}\text { presence of tourist } \\
\text { infrastructure }\end{array}$ & $\begin{array}{l}\text { more than } 10 \mathrm{~km} \\
\text { from the existing } \\
\text { tourist facilities }\end{array}$ & $\begin{array}{l}5-10 \mathrm{~km} \text { from the existing } \\
\text { tourist facilities }\end{array}$ & $\begin{array}{l}\text { less than } 5 \mathrm{~km} \text { from the exist- } \\
\text { ing tourist facilities }\end{array}$ \\
\hline & local products & lack & several products & $\begin{array}{l}\text { the place is a symbol for sever- } \\
\text { al local products }\end{array}$ \\
\hline \multirow[t]{4}{*}{$\begin{array}{l}\text { Conservation } \\
\text { value }\end{array}$} & $\begin{array}{l}\text { existing threats } \\
\text { and the risk of } \\
\text { damage }\end{array}$ & $\begin{array}{l}\text { natural and } \\
\text { anthropogenic } \\
\text { threats }\end{array}$ & $\begin{array}{l}\text { threat that may destroy the } \\
\text { site }\end{array}$ & $\begin{array}{l}\text { low risk and almost non-exist- } \\
\text { ing threat }\end{array}$ \\
\hline & $\begin{array}{l}\text { potential threats } \\
\text { and the risk of } \\
\text { damage }\end{array}$ & $\begin{array}{l}\text { natural and } \\
\text { anthropogenic } \\
\text { threats }\end{array}$ & $\begin{array}{l}\text { threat that may destroy the } \\
\text { site }\end{array}$ & $\begin{array}{l}\text { low risk and almost non-exist- } \\
\text { ing threat }\end{array}$ \\
\hline & current state & $\begin{array}{l}\text { continuous } \\
\text { destruction of the } \\
\text { site }\end{array}$ & $\begin{array}{l}\text { destroyed site but the ac- } \\
\text { tion is taken to stop further } \\
\text { destruction }\end{array}$ & no destruction \\
\hline & $\begin{array}{l}\text { legal protection } \\
\text { status }\end{array}$ & $\begin{array}{l}\text { lack of legal pro- } \\
\text { tection }\end{array}$ & $\begin{array}{l}\text { existing proposals of legal } \\
\text { protection }\end{array}$ & effective legal protection \\
\hline \multirow[t]{3}{*}{ Added value } & $\begin{array}{l}\text { cultural values } \\
\text { (historical, archae- } \\
\text { ological, religious) } \\
\text { connected with the } \\
\text { abiotic site } \\
\end{array}$ & lack & $\begin{array}{l}\text { existing cultural values but } \\
\text { but without a close connec- } \\
\text { tion with the abiotic site }\end{array}$ & $\begin{array}{l}\text { existing cultural values in close } \\
\text { connection with the abiotic site }\end{array}$ \\
\hline & ecological value & unimportant & $\begin{array}{l}\text { existing influence but with- } \\
\text { out much significance }\end{array}$ & $\begin{array}{l}\text { important influence of geomor- } \\
\text { phological features on ecologi- } \\
\text { cal value of the site }\end{array}$ \\
\hline & $\begin{array}{l}\text { aesthetic value } \\
\text { (number of colours, } \\
\text { structure types, } \\
\text { viewpoints) }\end{array}$ & $\begin{array}{l}0-1 \text { colour, } \\
0.25-2-3 \text { col- } \\
\text { ours, } \\
0.5 \text { - more than } 3 \\
\text { colours }\end{array}$ & \begin{tabular}{|l|}
$0-$ only 1 structure, \\
$0.25-2-3$ clearly distin- \\
guishable structures, \\
0.5 - more than 3 structures
\end{tabular} & $\begin{array}{l}0-\text { lack of observation points, } \\
0.25-1-2 \text { observation points, } \\
0.5-3 \text { and more observation } \\
\text { points }\end{array}$ \\
\hline
\end{tabular}


assets of which are technical-cultural and historical values, the geomorphological heritage was highlighted.

2. Selection of ten geosites, evenly distributed along the trail. The selected geosites represent convex and concave landforms, hydrological objects, erratics; the list included also objects of cultural heritage that are interesting from a geological/geomorphological aspect.

3. Evaluation of geosites. The following values (categories) have been evaluated: scientific value, educational value, economic value, conservation value, and added value. The categories, together with 18 attributed criteria and scores brackets (Table 1 ), refer to the conception published by Kubalíkova (2013).

It should be noted that Kamienska and Giemza (2014) evaluated recently all geosites (56) in the planned geopark area in terms of their geotourist attractiveness. They took into account somewhat different categories (accessibility, degree of preservation of original state, scientific value, and educational value) and considerably smaller number of criteria. In this paper we refer only to the evaluation results obtained by the mentioned authors for these geosites, which are located mainly along the geotouristic path "Połczyn Switzerland" (20 geosites). The name "Switzerland" might be somewhat confusing, but it suggests a very diverse relief of the region. As the compared groups of geosites differ in the number of sites and categories, the results of comparative analysis can be considered only as supporting information.

Taking into account similar examples known from foreign literature (among others Reynard 2004, 2005, Dowling 2013), we think that there is a high probability that the geosites described in this paper, due to their scientific and educational potential as well as aesthetic value, can become a tourist attraction, which will favour the development of geotourism, and consequently the sustainable socio-economic development of the districts in which they are located.

Conservation of geological heritage and its geodiversity, as well as ecological education are recommended tasks in the field of environmental geology (in the years 2008-2015). Ministry of the Environment published the guidelines on these problems (MS 2016). The section 3.3. contains the following statement: "in order to protect natural resources and cultural heritage it is essential to protect valuable geological and geomorphological sites, including the establishment of geoparks, i.e. the areas of complex geological heritage."

As defined by the Polish Geological Institute - National Research Institute, geopark is an area of outlined boundaries, in which there are places of significant scientific importance for geology, ecology, archaeology and culture. These places are called geosites. Due to an effective conservation of geosites it is possible to propagate their educational and tourist functions and promote geological sciences. Geopark is also a form of landscape management according to the modern principles of sustainable development (Alexandrowicz, Miśkiewicz 2016). The main objective of geoparks' establishment is to promote geological heritage through the conservation, tourist development, and adaptation to explore the geological objects called geosites.

Polish Central Register of Geosites (PIGPIB 2016) is the largest database on geosites in Poland. The listed geosites have been inventoried according to a uniform system. The description of each site includes general information, physical characteristics, current state, geological characteristics, graphic documentation, bibliography, and map. This register contains data of almost 60 geosites from the area of Drawskie Lake District.

Especially valuable sites are also inventoried in the regional offices of The General Directorate for Environmental Protection. However, these site descriptions do not contain detailed information on the origin and geological structure of the inanimate nature objects, as well as photographic documentation. It happens that the information is not updated.

\section{Study area}

The planned geopark will be located within the extent of the Parsęta lobe (Fig. 1), i.e. in the marginal zone of the last Scandinavian ice sheet that reached this area during the Pomeranian phase of the Vistulian glaciation $\left(15.2{ }^{14} \mathrm{C} \mathrm{ka}\right.$, Kozarski 1986, 1988, Marks 2002, 16.2 ka BP, Kozarski 1995, 14.8 $\pm 0.4{ }^{10} \mathrm{Be}$ ka, Rinterknecht et al. 2005, Marks 2011).

The geopark will occupy the area between the maximum and main course of end moraines 


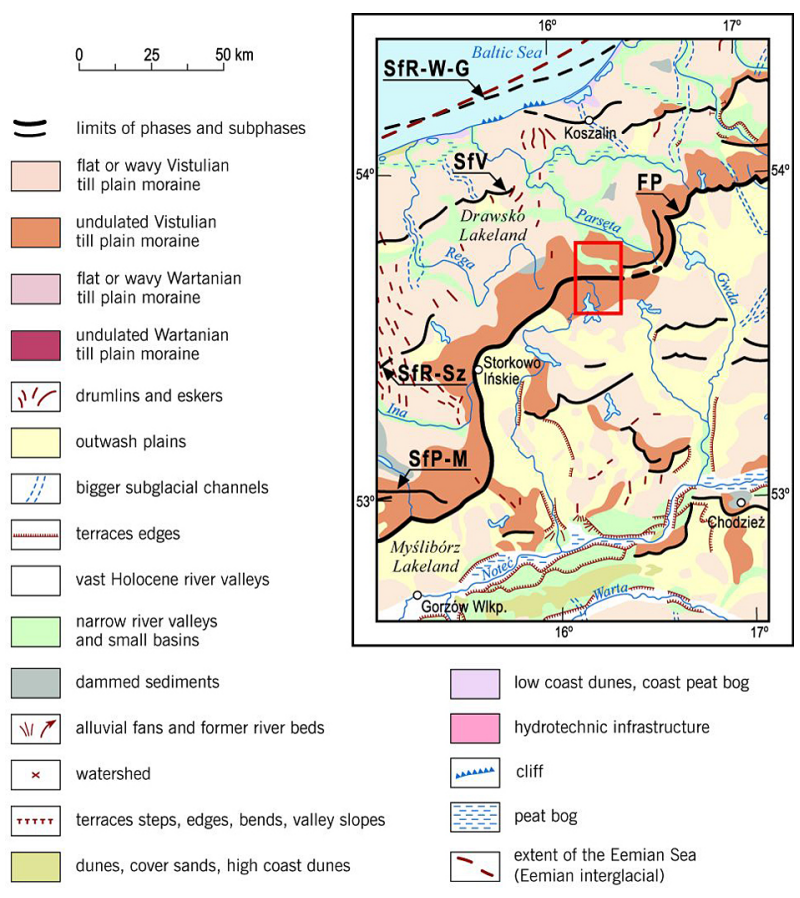

Fig. 1. The location of the planned geopark "PostGlacial Land of the Drawa and Dębnica" (within the red rectangle) on the geomorphological map of the north-western Poland (based upon Liedtke 1981, Bremer 1994).

Ice-sheet margins: FP - the Pomeranian Phase, SfP-M - the Penkun - Mielęcin Subphase, SfR-Sz - Rosenthal Szczecin Subphase, SfV - Velgaster Subphase, SfR-W-G - Rügen - Wolin - Gardno Subphase.

(Dobracka 2009a, b, Dobracka, Lewandowski 2002). Besides these forms, there are also other relief elements related to accumulation activity of ice sheet in this area, i.e. the ridges of end moraine of the Parsęta lobe (Chłopowskie Hills), push moraine ridge (Skąpa Hill, $135 \mathrm{~m}$ a.s.l., to the north of the village of Brusno), moraine plateau, kame hills (Skowroncze Hills in the north part of the geopark, Piaskowa Hill near the city of Barwice), esker ridges, and numerous erratics. Some glacial deposits are exploited in gravel and sand pits (e.g. in Ostrowąs, Kołacz, Kluczewo, Prosino). From among glacial erosional forms occurring in the geopark area the following should be mentioned: deep troughs, which are filled with water in places (e.g. Five Lakes Valley), marginal depressions (Dobracka, Lewandowski 2002) of Komorze Lake, Żerdno Lake, Drawsko Lake, which are also known as marginal troughs (Bartkowski 1972, Marsz 1971, 1973), basins of thaw lakes (e.g. Wierzchowo, Radacz, Wielimie, Trzesiecko), and small depressions without outflow, occurring in the hillocky moraine plateau, which were formed as a result of thawing of dead-ice blocks.

Within the boundaries of the planned geopark there are also the examples of forms developed as a result of spring hydrogeological phenomena (spring and seepage areas, groundwater outflows) as well as fluvial forms (ravines, gullies, water gaps, first rank watershed). The elements of geological and cultural heritage merge together, and this phenomenon is represented e.g. by the ancient archaeological objects, sacred and secular stone objects, and technical development (mills) of rapid streams.

A relatively small area (about $350 \mathrm{~km}^{2}$ ) of the planned geopark named "Postglacial land of the Drawa and Dębnica rivers" is characterized by the occurrence of many genetically diverse landforms and deposits. Such a large diversity of the abiotic environment is called geodiversity (Kozłowski 1997, Kostrzewski 1998, Gray 2004, Zwoliński 2004, Zwoliński and Stachowiak 2012). Kostrzewski (2011) expands this definition, adding that it is the diversity of all elements of abiotic environment, i.e. geological structure, relief, soils, climate and surface water and groundwater, at different levels of synthesis of geographical space and under various anthropogenic influences. We must not forget that geodiversity is the basis for biodiversity, and together they constitute the diversity of landscape structure on the Earth's surface, including the area of the planned geopark. The geodiversity and biodiversity of the postglacial landscape in nearby Dębnica river catchment (which partially covers the area of the current research) were presented lately by Najwer et al. (2016).

\section{"Połczyn Switzerland" geotourist path and its geosites}

Walk along the planned "Połczyn Switzerland" geotourist path is the best way to explore the hilly part of the Drawskie Lake District. It will be the longest $(45 \mathrm{~km})$ of the five tourist paths in the planned geopark, and the walk along it can take nine hours. In contrast to other proposed four paths, it will not make a loop. It will run longitudinally from Połczyn-Zdrój in the north to Czaplinek in the south, mainly along the existing walking and bike trails. The trail will 


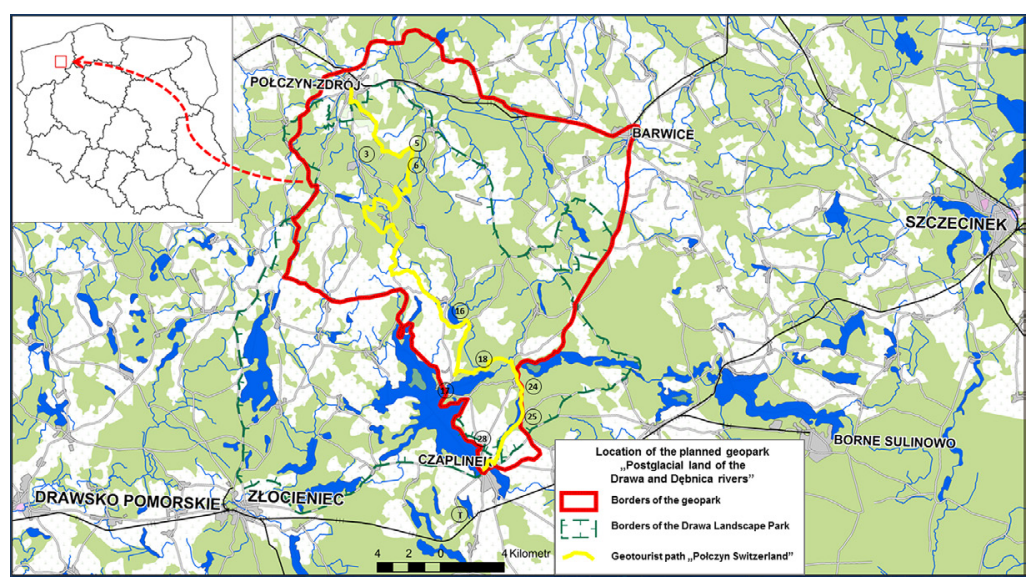

Fig. 2. The "Połczyn Switzerland" geotourist path with marked geosites acc. Kamieńska, Giemza (2013). The boundaries of the planned geopark "Postglacial land of the Drawa and Dębnica rivers" as well as boundaries of the Drawski Landscape Park are marked in the map.

Table 2. Geosites (described in this paper, marked in grey) and other places worth seeing

along the "Połczyn Switzerland" geotourist path.

\begin{tabular}{|l|}
\hline 1. Castle in Połczyn-Zdrój \\
\hline 2. Spa Park (information board) \\
\hline 3. Small thaw lakes in moraine plateau \\
\hline 4. Valley with accumulation of boulders \\
\hline $\begin{array}{l}\text { 5. Ravine of the Bliska Struga Stream and its tributaries } \\
\text { (information board) }\end{array}$ \\
\hline 6. Springs in the Ravine of the Bliska Struga Stream \\
\hline 7. Depressions without outflow in moraine plateau \\
\hline 8. Two erratics \\
\hline 9. Lake Krzywe \\
\hline $\begin{array}{l}\text { 10. Observation point over the Valley of Five Lakes } \\
\text { (board) }\end{array}$ \\
\hline 11. Gravel pit in Czarnków \\
\hline 12. Wola Góra hill (information board) \\
\hline 13. Small thaw lakes in moraine plateau \\
\hline 14. Erratic in Kolonia Bolegożyn \\
\hline 15. Museum of State Agricultural Farm \\
\hline 16. Lake Prosino \\
\hline 17. Observation tower on the Spycz(y)na Góra hill \\
\hline 18. Drahim Castle (information board) \\
\hline 19. Gravel pit in Żerdno \\
\hline 20. Observation point and erratic \\
\hline 21. Observation point over Lake Komorze \\
\hline $\begin{array}{l}\text { 22. Observation point over the trough of Lake Żerdno } \\
\text { and Lake Komorze }\end{array}$ \\
\hline 23. Church in Sikory \\
\hline 24. Pottery Settlement in Sikory (information board) \\
\hline 25. Erratics on Lake Dołgie Wielkie \\
\hline 26. Erratic \\
\hline 27. Lake Dołgie Wielkie \\
\hline $\begin{array}{l}\text { 28. Pleistocene tors of the Lipowa Góra hill near Łazice } \\
\text { (information board) }\end{array}$ \\
\hline 29. Museum room in Czaplinek \\
\hline 30. Erratic \\
\hline 31. Sławogród \\
\hline
\end{tabular}

be marked out in such a way that tourists will get to know all key values of the Postglacial land of the Drawa and Dębnica rivers.

As many as 31 sites occurring along the trail (Fig. 2, Table 2) are worth seeing. Among them there are the following 10 geosites, the evaluation of which is presented in this paper: small thaw lakes in moraine plateau (No. 3 in Fig. 2 and Table 2), Ravine of the Bliska Stream (No. 5), springs in the Ravine of the Bliska Stream and its tributaries (No. 6), Prosino Lake (No. 16), observation tower on the Spycz(y)na Hill (No. 17), Drahim Castle (No. 18), Pottery Settlement in Sikory (No. 24), erratics on Dołgie Wielkie Lake (No. 25), Pleistocene rocks of the Lipowa Hill near Łazice (No. 28), Tempelburg boulder. The last object is situated outside the planned geopark. However, it has been included to the analysis because it is an example of unique geological and historical heritage of the region.

Nine evaluated geosites are marked with grey colour, and their numbers are the same as in Fig. 2. The tenth evaluated geosite - Tempelburg boulder ( $\mathrm{T}$ in a circle, in Fig. 2) - is situated outside the planned geopark.

\section{Overview of geosites along the "Połczyn Switzerland" geotourist path}

The overview of geosites located along the "Połczyn Switzerland" geotourist path is given from the north to the south. The number in parentheses next to the name of each geosite corresponds to the numbering used in Table 2. 


\section{Small thaw lakes in hummocky moraine plateau (No. 3)}

Glacial relief of this hummocky part of the Drawskie Lake District is varied due to the occurrence of numerous, small, dead-ice depressions which are adjacent to the hills. The concave forms, common in the region, are filled with water because the bedrock is composed of impermeable till. Tourist trail leads to the well-exposed observation point over a small thaw lake in the depression of basal moraine so the access to this geosite is easy.

\section{Ravine of the Bliska Stream (No. 5)}

The Bliska Stream and its small tributaries formed a very deep ravine; its sides are almost vertical and over $70 \mathrm{~m}$ high in places (Figs 3, 4). The sides are covered by beech and oak woods. It is planned to set an information board in the geosite.

\section{Springs in the Ravine of the Bliska Stream} (No. 6)

Spring hydrogeological phenomena, which are typical of the Drawskie Lake District area, can be observed in the ravine (Mazurek 2006,
Mazurek et al. 2010). Spring and seepage areas, occurring in numerous spring niches, discharge water from the water-bearing beds cut by erosion (Fig. 3 and 4). Water percolates through the thick layer of tills, which are rich in calcium, and leaches this element. Then calcium carbonate precipitates in the bottoms of spring niches forming the so-called "calcareous tufa". Water flowing from the springs is hard $\left(276.0 \mathrm{mg} \mathrm{CaCO}_{3} / \mathrm{l}\right.$; Mazurek et al. 2010).

One of the sources occurring in the Ravine of the Bliska Stream is a favourite water hole for forest animals, which is a great attraction for the tourists wishing to see wild animals.

\section{Prosino Lake (No. 16)}

Travelling southwards along the road No. 163 from Połczyn-Zdrój, just leaving Kluczewo, we can see on the left the large surface of Prosino Lake. It is an example of thaw lake, which was formed after the thawing of dead-ice mass. It is located at the mouth of the Drawa River channel, i.e. about $2 \mathrm{~km}$ to the south of the main extent of the last ice sheet during the Pomeranian phase (Dobracka, Lewandowski 2002).

Small depth of the lake favours the development of rush vegetation, which forms a belt over $50 \mathrm{~m}$ wide in places. Luxuriant shore vegetation

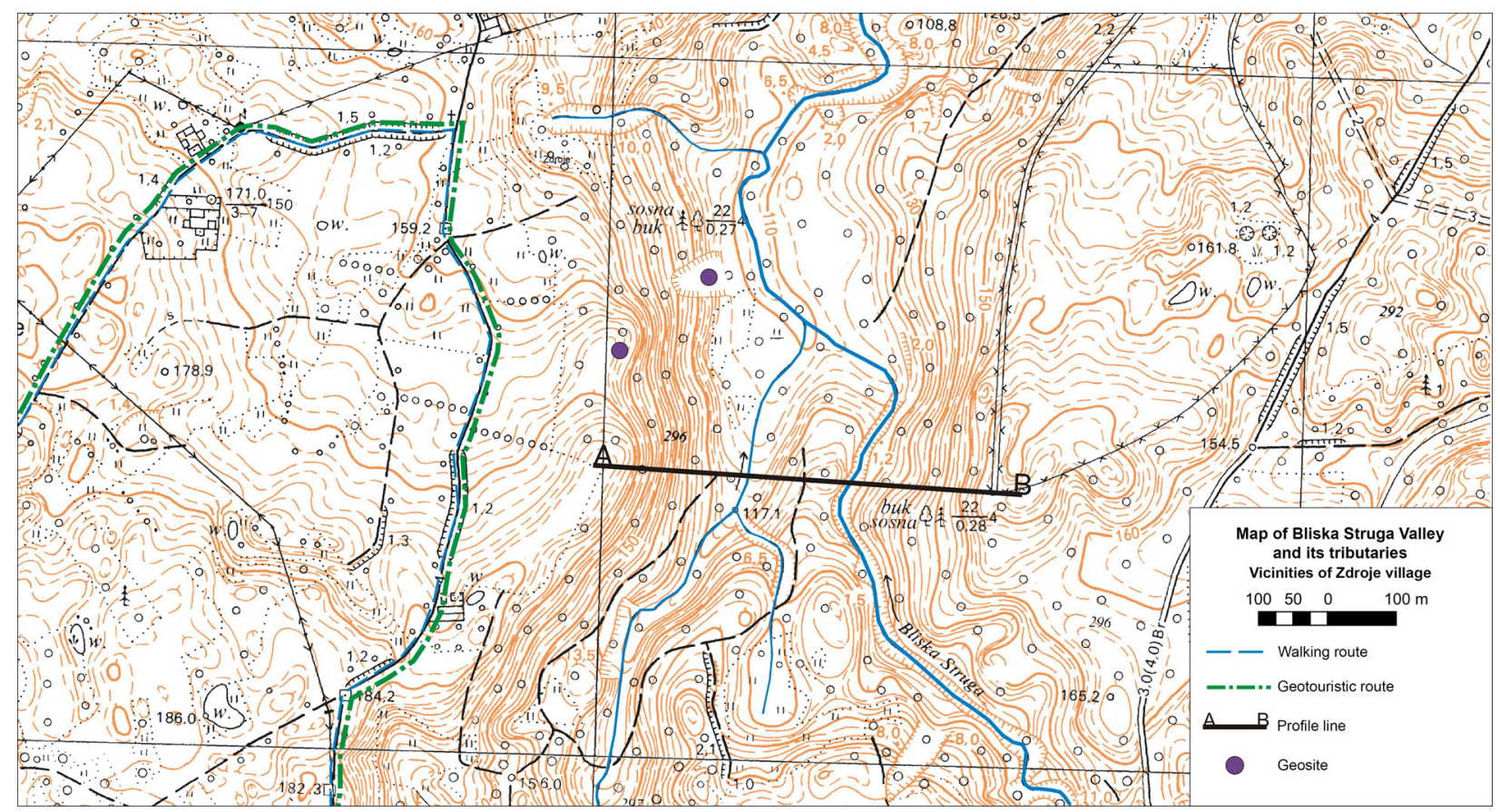

Fig. 3. Topographic map with the line of geological cross-section through the Ravine of the Bliska Stream and its tributaries acc. to Kamieńska, Giemza (2013). 


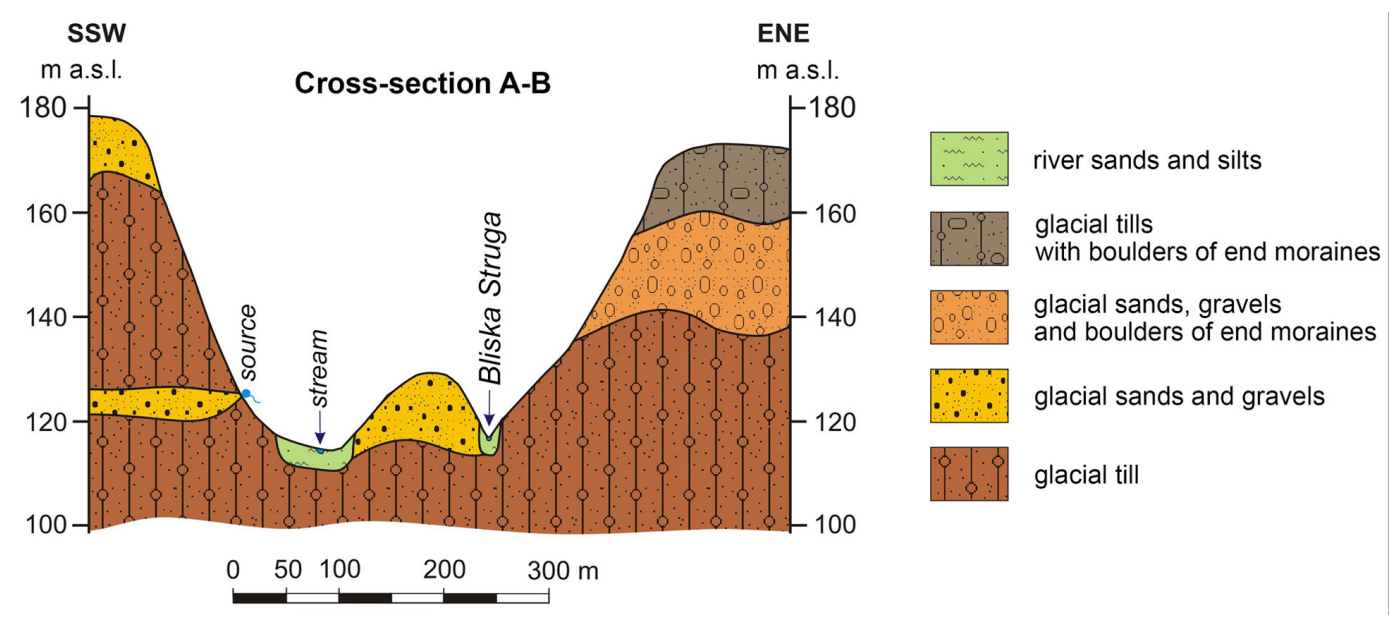

Fig. 4. Geological cross-section through the Ravine of the Bliska Stream and its tributaries acc. to Kamieńska, Giemza (2013).

and the occurrence of swamp hinder access to the lake, forming favourable conditions for living and hatching of 26 rare species of water and mud birds (Hołubczat 2010). This habitat of avifauna is listed in the Habitats and Birds Directive. Prosino Lake is also an important place for water birds to flock together during their spring and autumn migrations. In order to protect the habitats of these birds, Prosino Lake has been put under legal protection in the form of ornithological reserve. Due to its biodiversity the reserve is an attractive object for scientific research.

Access to the lake is only possible from the south-west, where the resting shed is located. At a somewhat greater distance from the southern shore of the lake there is a small illegal sandpit, where (geo)tourists can observe the geological structure of the Drawa River outwash plain (Górska-Zabielska 2008), and reconstruct the course of geomorphological events in the icesheet foreland. At the northern end of the lake there is a conical hill of early medieval guard castle from the 14th.

Location of the lake in the Drawski Landscape Park and NATURA 2000 area ("Drawa Refuge" Special Protection Birds Area No. PLB320019, "Czaplinek Lakes" Special Areas of Habitat Protection No. PLH320039), excellent opportunity to observe avifauna, and the traces of cultural heritage involving geomorphology make the lake a very attractive object of the planned geopark due to its geotourist and educational values.

\section{Observation tower on the Spycz(y)na Hill (No. 17)}

The Spycz(y)na Hill (203 m a.s.1.) is one of the highest hills in the Drawskie Lake District area. It is located in the recessional moraine course formed in the Pomeranian Phase. The Spycz(y)na Hill rises on the northern shore of Żerdno Lake (called also Srebrne Lake), the water level of which occurs at $128.4 \mathrm{~m}$ a.s.l. (Dobracki 2002a).

The view from the observation tower on the Spycz(y)na Hill is blocked by forest. However, a new, higher observation platform is under construction. (Geo)tourists will be able to admire the young glacial relief of the geopark from this platform, and especially the top parts of end moraine representing the main extent of the Parsęta lobe during the Pomeranian phase of the last glacial. The diversified relief of this region is protected as part of the Drawski Landscape Park and the protected landscape area of the Drawskie Lake District.

A much better view stretches from the second observation tower existing in the area of planned geopark. Fire observation tower, which is $48 \mathrm{~m}$ high and belongs to the Połczyn-Zdrój Forestry Commission, is located on the Wola Hill (223 m a.s.l., Dobracki 2002b), about $4 \mathrm{~km}$ to the east of Toporzyk (Głąbiński 2009). It provides (in 2013 year) a wide (within a radius of several kilometres) panorama of the Drawskie Lake District. The observation tower is open to tourists in the period from May to late September. 


\section{Drahim Castle (No. 18)}

Drahim Castle, built in 1366 by the Knights of St. John, is one of the most valuable cultural heritage objects in the planned geopark. It is an example of the use of natural conditions in the construction of fortifications. Due to the existence of the hill and isthmus between the lakes, as well as the availability of building materials (erratic boulders), it was possible to build one of the most important strongholds in the northern borders of Poland in days of the Drahim county (Głąbiński 2009).

Today the castle is easily accessible as it is located on the road No. 163 connecting the Połczyn and Czaplinek cities, and on the tourist trails (red and green). The castle is well exposed, cleared of vegetation and protected from further decay. The outer defensive walls and the remains of the main house of the castle are preserved. During the holiday season the administrator of the castle, in cooperation with the local government and knight fraternities, organizes a series of events under the name of "Summer with the history", in order to promote the region and restore the former glory of ruins. The culmination of these events is the reconstruction of stronghold capture, which took place in 1407 year. It is held in mid-August, and combined with a knight tournament, dances and concerts of court music (Bednarek 2016).

\section{Pottery Settlement in Sikory (No. 24)}

Medieval inhabitants of the village of Sikory knew how to make use of good quality till. As a result, they became famous for the production of pottery and bricks. The upper parts of the walls of nearby Drahim Castle were probably built of bricks produced in Sikory. In 2003, in order to restore the traditions and attract tourists, it was decided to reconstruct the Pottery Settlement. Today tourists can see in this ecomuseum (sensu Zaręba 2010, Buczek-Kowalik et al. 2013) the reconstructed kiln and small exhibition-workshop room. Pottery workshops for tourists are organized in Sikory in the summer.

\section{Erratics on Dołgie Wielkie Lake (No. 25)}

Within the planned geopark there are about 15 large erratics occurring in situ, and several places with erratics accumulated ex situ, including the lapidarium (located in Żurawiec) of erratics collected in the Drawskie Lake District (Górska-Zabielska 2013). All locations of erratics are marked on the Geotourist Map at a scale of 1:25000.

Two large erratics occur on the eastern shore of the ribbon Dołgie Wielkie Lake. Both are located on the blue tourist trail and well exposed, so it should not be difficult to get to them. Their scientific and educational value is high because they belong to the group of indicator erratics (Górska-Zabielska 2008). Both are boulders of the Småland granite, which has outcrops in the south-eastern Sweden. They have different sizes. The erratic (No. 43 on the Geotourist Map at a scale of 1:25 000) occurring on the path surrounding the lake, in the middle of its eastern shore, is much larger. Based on the known relations (Górska-Zabielska 2010), the volume of this erratic is estimated at $4.71 \mathrm{~m}^{3}$, and the weight - at almost 13 tonnes. The erratic (No. 44 ) occurring on the road leading to the Sikory forester's lodge, about $50 \mathrm{~m}$ from the edge of the forest, has a volume of $1.57 \mathrm{~m}^{3}$ and weighs 4.33 tonnes.

The erratics occurring on the eastern shore of Dołgie Wielkie Lake are protected by law in the form of inanimate nature monuments. The larger of them is called the Devil's Stone, and a local legend is connected with it (Bojar-Fijałkowski 1977). Cultural values, i.e. folk tales connected with the site, increase the geotourist attractiveness of this erratic.

\section{Pleistocene tors of the Lipowa Hill near Eazice (No. 28)}

It is one of the few West Pomeranian sites with consolidated glaciofluvial deposits representing the last glacial (Kłysz 1992, Gruszka et al. 2002). From geomorphological point of view, the Lipowa Hill is a single kame located in the inner zone of the ice-sheet maximum extent during the Pomeranian phase (Gruszka et al. 2002).

The Vistulian glaciofluvial and glaciolacustrine consolidated deposits are exposed in the northern wall of abandoned sandpit. They form small tors composed of glaciofluvial sand and gravel cemented mainly by calcium carbonate. In periglacial zone, calcium carbonate was leached 
from till and precipitated in the underlying sandy-gravelly layer. This process resulted in zonal consolidation of loose deposits. The blocks of conglomerate with clayey-carbonate cement have been exposed in the wall of sandpit as a result of sand exploitation.

During the field work (2012) the state of geosite preservation was far from satisfactory; moreover, it looked gradually deteriorating. The lack of exploitation has resulted in the encroachment of grass and shrub vegetation on the sandpit walls, and the Pleistocene tors are hidden. Moreover, the tors occur in loose sandy-gravelly deposits, which facilitate their gravitational moving down the wall. An additional natural factor destroying the tors is weathering process, which results in the reduction of their size. The excavation will probably be reclaimed, so the tors, which are valuable due to their origin and fancy shapes, may be completely degraded.

The geosite is easily accessible; it is located near the Czaplinek-Sikory bike blue trail. It occurs in the protection zone of the Drawski Landscape Park and NATURA 2000 area ("Drawa Refuge" Special Protection Birds Area No. PLB320019). It is an extremely interesting place on the geotourist map of the region.

\section{"Tempelburg" boulder}

The boulder is situated outside the planned geopark but this fact in no way detracts from its geotourism potential. As the largest boulder in the Drawski Landscape Park it is often mentioned as one of local tourist attractions. On the Geotourist Map at a scale of 1:25 000 it is marked with No. 46.

It is not difficult to get to this erratic. The route leading to the boulder is signposted at the intersection of asphalt road Czaplinek - Stare Kaleńsko with dirt road running from Pławno to Cichorzecze. Tourists can also reach the boulder travelling along the "Lobelia Lakes" bike trail, which is marked with a stylized bike silhouette in black colour.

The boulder is protected by law as an inanimate nature monument due to its size $(19 \mathrm{~m}$ in circumference, and $3.5 \mathrm{~m}$ in height above the ground surface), location in situ, and historical importance (Fig. 5). It served as the border stone, marking the south-western extent of the Drahim county. Unfortunately, this fact has not been reflected in the name of the boulder; even today the boulder does not have an official name. On the old maps (DSI 2016) it is named Der Geklöbte Stein or Der Geklobte Stein, which rather indicates anthropogenic destruction (attempts to split the stone into smaller pieces).

\section{Evaluation of geosites}

\section{Scientific value}

From among ten analysed geosites, Prosino Lake (No. 16, Table 3) has got the maximum number of scores (4) in the category of scientific value. The lake stands out from other geosites because it is a separate object of research. Drahim Castle (No. 18), Pottery Settlement in Sikory (No. 24), and Pleistocene tors of the Lipowa Hill near Łazice (No. 28) have got 3 scores. Each of them is unique in regional scale, and gives tourists the opportunity to observe the effects of several different geological and geomorphological processes (e.g. glacial erosion and transport, deposition of Scandinavian erratics, periglacial processes, present-day slope processes).

Scientific value of most geosites has been evaluated at 2.5 scores. These are the following objects: Ravine of the Bliska Stream (No. 5), springs in the Ravine of the Bliska Stream (No. 6), observation tower on the Spycz(y)na Hill (No. 17), erratics on Dołgie Wielkie Lake (No. 25), and Tempelburg boulder. These geosites have not very high scientific value because (geo)tourists can observe there the results of only one-two geological/geomorphological processes. Moreover, such processes are also observable in other, similar objects occurring in the planned geopark.

Scientific value of small thaw lakes in moraine plateau (No. 3) is the lowest.

\section{Educational value}

As many as four geosites (Table 3) have been evaluated at 4 scores, i.e. the maximum number in the category of educational value: observation tower on the Spycz(y)na Hill (No. 17), Drahim Castle (No. 18), Pottery Settlement in Sikory (No. 24), and Tempelburg boulder. These are geosites where (geo)tourists can get information on the visited region in the most effective way. 


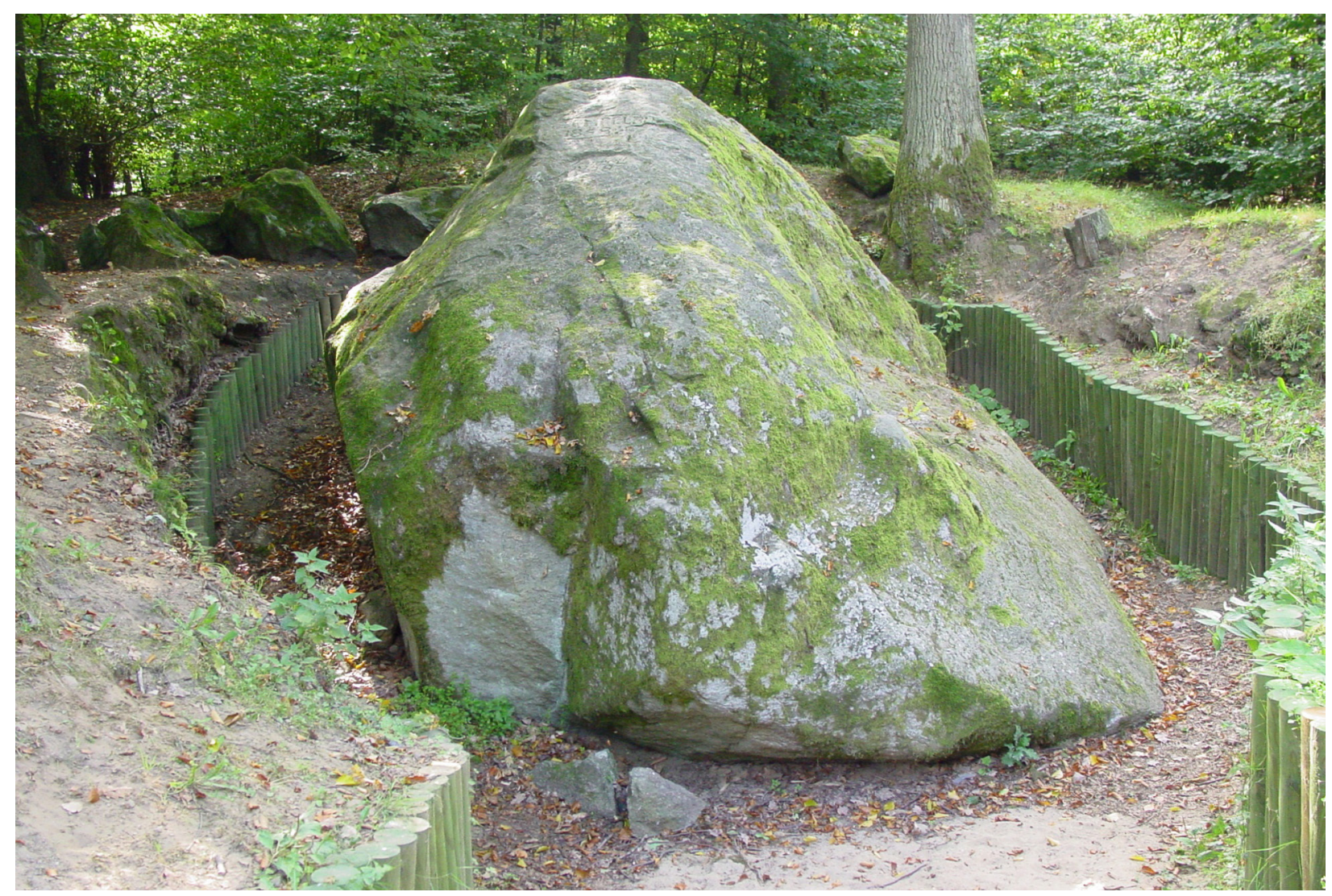

Fig. 5. "Tempelburg" boulder is the biggest inanimate monument located in the vicinity of the planned geopark (phot. M. Górska-Zabielska, 2009).

The objects are large and everyone, without special preparation, is able to assimilate knowledge about them. In each of the successive six geosites the effective transmission of knowledge is gradually less successful. The springs in the Ravine of the Bliska Stream (No. 6) and Prosino Lake (No. 16) have got 3 scores. The Ravine of the Bliska Stream and its tributaries (No. 5), and erratics on Dołgie Wielkie Lake (No. 25) have got 2.5 scores. Educational value of the small thaw lakes in moraine plateau (No. 3) and Pleistocene tors of the Lipowa Hill near Łazice (No. 28) is the lowest (2 scores).

\section{Economic value}

Geosites, which are evaluated highly in respect of their existing or potential economic value, can be a driving force of geotourism development, and consequently the economic development of a region. In the study area, none of the analysed geosites has got the maximum number (3) of scores. This means that there is not any strong motor force, which can affect the development of the entire region. The analysed geosites have not the same specialization in the field of economy; these are, or can be in the future, small independent economic ventures.

Three geosites have been evaluated at 2.5 scores: Drahim Castle (No. 18), Pottery Settlement in Sikory (No. 24), and Tempelburg boulder. The following three geosites have got half of the scores available in the category of economic value: Prosino Lake (No. 16), observation tower on the Spycz(y)na Hill (No. 17), and erratics on Dołgie Wielkie Lake (No. 25). The Ravine of the Bliska Stream and its tributaries (No. 5), springs in the Ravine of the Bliska Stream (No. 6), and Pleistocene tors of the Lipowa Hill near Łazice (No. 28) have got 1 score. For the third time the geosite of small thaw lakes in moraine plateau (No. 3) has got the minimum number (0.5) of scores.

\section{Conservation value}

Three from among ten geosites were very well preserved (4 scores) at the time of field work. 
Table 3. Assessment of selected geosites in the Drawskie Lake District concerning the scientific, educational, economic, conservation and added values.

\begin{tabular}{|c|c|c|c|c|c|c|c|c|c|c|c|c|c|c|c|c|c|c|c|}
\hline \multirow[b]{2}{*}{$\begin{array}{l}\text { Small thaw lakes in moraine } \\
\text { plateau }\end{array}$} & \multicolumn{4}{|c|}{$\begin{array}{l}\text { Scientific } \\
\text { value }\end{array}$} & \multicolumn{4}{|c|}{$\begin{array}{c}\text { Educational } \\
\text { value }\end{array}$} & \multicolumn{3}{|c|}{$\begin{array}{l}\text { Economic } \\
\text { value }\end{array}$} & \multicolumn{4}{|c|}{$\begin{array}{l}\text { Conservation } \\
\text { value }\end{array}$} & \multicolumn{3}{|c|}{$\begin{array}{l}\text { Added } \\
\text { value }\end{array}$} & \multirow{2}{*}{\begin{tabular}{|l|} 
Total \\
10.25
\end{tabular}} \\
\hline & 1 & 0 & 0.5 & 0.5 & 0.5 & 0.5 & 0.5 & 0.5 & 0 & 0.5 & 0 & 1 & 1 & 1 & 1 & 0 & 1 & 0.75 & \\
\hline $\begin{array}{l}\text { Springs in the Ravine of the } \\
\text { Bliska Struga Stream }\end{array}$ & 1 & 0 & 1 & 0.5 & 1 & 1 & 0.5 & 0.5 & 0 & 1 & 0 & 1 & 0 & 1 & 1 & 0 & 1 & 0.75 & 11.25 \\
\hline $\begin{array}{l}\text { Ravine of the Bliska Struga } \\
\text { Stream }\end{array}$ & 1 & 0 & 1 & 0.5 & 0.5 & 1 & 0.5 & 0.5 & 0 & 1 & 0 & 1 & 1 & 1 & 1 & 0 & 1 & 1.5 & 12.5 \\
\hline Lake Prosino & 1 & 1 & 1 & 1 & 0.5 & 1 & 1 & 0.5 & 0.5 & 1 & 0 & 0 & 0 & 1 & 1 & 0 & 1 & 1 & 12.5 \\
\hline $\begin{array}{l}\text { Observation tower on the } \\
\text { Spycz(y)na Góra hill }\end{array}$ & 0.5 & 0.5 & 1 & 0.5 & 1 & 1 & 1 & 1 & 0.5 & 1 & 0 & 0.5 & 0.5 & 0.5 & 1 & 0 & 1 & 1 & 12.5 \\
\hline Pottery Settlement in Sikory & 1 & 1 & 0.5 & 0.5 & 1 & 1 & 1 & 1 & 0.5 & 1 & 1 & 1 & 1 & 1 & 1 & 1 & 0 & 1.5 & 16 \\
\hline Drahim Castle & 0.5 & 1 & 0.5 & 1 & 1 & 1 & 1 & 1 & 0.5 & 1 & 1 & 0.5 & 0.5 & 0.5 & 1 & 1 & 0.5 & 1.5 & 15 \\
\hline $\begin{array}{l}\text { Erratics on Lake Dołgie } \\
\text { Wielkie }\end{array}$ & 1 & 0 & 1 & 0.5 & 0.5 & 1 & 0.5 & 0.5 & 0.5 & 1 & 0 & 0 & 0 & 1 & 1 & 0.5 & 0.5 & 1.5 & 11 \\
\hline $\begin{array}{l}\text { Pleistocene tors of the Lipowa } \\
\text { Góra hill near Łazice }\end{array}$ & 0.5 & 1 & 1 & 0.5 & 0.5 & 0.5 & 0.5 & 0.5 & 0 & 1 & 0 & 0.5 & 0 & 0 & 0.5 & 0 & 1 & 0.5 & 8.5 \\
\hline “Tempelburg” boulder & 1 & 0 & 1 & 0.5 & 1 & 1 & 1 & 1 & 1 & 1 & 0.5 & 0.5 & 0.5 & 0.5 & 1 & 1 & 0 & 1 & 13.5 \\
\hline
\end{tabular}

Due to the absence of potential threats, it is expected that their status will be not much worse in the future, and their conservation value will not decrease. These are the following geosites: small thaw lakes in moraine plateau (No. 3), Ravine of the Bliska Stream and its tributaries (No. 5), and Pottery Settlement in Sikory (No. 24, Table 3). Two geosites represent a little worse state of preservation: springs in the Ravine of the Bliska Stream (No. 6), and erratics on Dołgie Wielkie Lake (No. 25). The following geosites have got 2.5 scores because they are often visited by tourists, and consequently destroyed and threatened with further deterioration: observation tower on the Spycz(y)na Hill (No. 17), Drahim Castle (No. 18), and Tempelburg boulder. Despite legal protection in the form of natural reserve, Prosino Lake is constantly threatened by a decrease in the conservation value. This is caused by the situation of the lake between two villages, near a busy transit road, and also by the fact that tourists have access to water from the south. It cannot be excluded that the Drawa River that flows into the lake and chemicals from the surrounding fields degrade water quality. The Pleistocene tors of the Lipowa Hill near Łazice (No. 28) are threatened with the greatest destruction. The lack of any protection and the occurrence of the tors in loose deposits subjected to sliding result in a gradual deterioration in their state of preservation. The conservation value of this geosite has been evaluated at 1 score only.

\section{Added value}

In contrast to other categories, the criteria used in this category are more extended. The evaluation of a geosite includes also its cultural values, which are connected with abiotic environment. These can be historical, archaeological, religious, or ethnographic elements. Interesting ecological value of a geosite also raises its final evaluation. In the opinion of tourists, and especially geotourists, aesthetic value of a geosite is important. The diversity of colours and structures (shapes) found in a geosite, as well as the opportunity to observe it from different perspectives, make it more interesting for tourists.

None of the analysed geosites has got the maximum number (3.5) of scores in the category of added value. Drahim Castle (No. 18) and erratics on Dołgie Wielkie Lake (No. 25) are the objects of the highest added values ( 3 scores). The Ravine of the Bliska Stream and its tributaries (No. 5), and Pottery Settlement in Sikory (No. 24) have got 2.5 scores. The following geosites have been evaluated at 2 scores: Prosino Lake (No. 16), observation tower on the Spycz(y)na Hill (No. 17), and Tempelburg boulder. The small thaw lakes in moraine plateau (No. 3), and springs in the Ravine of the Bliska Stream (No. 6) have got half of the scores available in the category of added value, i.e. 1.75. Added value of the Pleistocene tors of the Lipowa Hill near Łazice (No. 28) is the lowest. 


\section{Final remarks}

Evaluation of ten geosites in the planned geopark has been carried out in order to indicate whether the geotourism potential of the selected objects will make possible the development of this new form of tourism in the catchment of Drawa and Dębnica rivers. In other words, to find whether the analysed values, which characterize each of the studied geosites, will contribute to the sustainable socio-economic development of the region.

The results of evaluation (Tables 3, 4) indicate that none of ten studied geosites of the Drawskie Lake District has remarkable geotourism potential. This conclusion is in line with the assessment of geotourist attractiveness of the geosites occurring in this part of the catchment, published by Kamieńska and Giemza (2014).

In the light of conducted analysis (Tables 3, 4), two geosites have high geotourism potential: Pottery Settlement in Sikory (16 scores) and Drahim Castle (15 scores). These sites are cultural and historical heritage objects. However, they have also a close connection with the inanimate nature due to the occurrence of stone material used to erect the building (Drahim Castle) and educational function (production of pottery from till in Sikory).

Geotourist attractiveness of the Pottery Settlement in Sikory has been highly evaluated (7.5/10 scores) also by Kamieńska and Giemza (2014). They have assessed similarly high the following sites: the ornithological reserve of Prosino Lake, observation tower on the Wola Hill, and springs in the Ravine of the Bliska Stream.

Seven geosites have average geotourism potential. These are the following sites (from the highest to the lowest number of scores in this range): Tempelburg boulder (13.5), ex aequo Ravine of the Bliska Stream and its tributaries, Prosino Lake, observation tower on the Spycz $(y)$ na Hill, erratics on Dołgie Wielkie Lake (12.5), springs in the Ravine of the Bliska Stream (11.25), and small thaw lakes in moraine plateau (10.25). All geosites classified to this group are good educational objects, because they provide a diverse knowledge in the field of geology and geomorphology. Therefore, they have high research and educational potential. Unfortunately, none of these seven geosites represents specific economic values, which are important in the socio-economic development of the region. The geosites are
Table 4. Final ranking of geotourism potential based upon the analysis of the selected geosites in the Drawskie Lake District.

\begin{tabular}{|c|c|}
\hline Number of scores & Geotourism potential \\
\hline $17-18.5$ & remarkable \\
\hline $14-16.75$ & high \\
\hline $9-13.75$ & average \\
\hline below 8.75 & low \\
\hline
\end{tabular}

not connected with any local products, and their availability leaves a lot to be desired.

Geotourist attractiveness of vast majority of the 20 geosites, which were studied by Kamieńska and Giemza (2014) in the hilly part of the Drawskie Lake District (= "Połczyn Switzerland"), has been assessed by them as average, and this is in line with the results of our study.

It seems that there is no chance that the Pleistocene tors of the Lipowa Hill near Łazice, which have the lowest geotourism potential $(8.5$ scores), will contribute to the development of geotourism, and consequently to the socio-economic development of the region. However, this geosite has been differently evaluated by Kamieńska and Giemza (2014). Taking into account four categories of geotourist attractiveness, they classified this geosite in fifth place.

Based on the evaluation of different geosites, occurring in the planned geopark named "Postglacial land of the Drawa and Dębnica rivers" and representing both inanimate nature and cultural heritage, we find that those being anthropogenic objects are most likely to favour the sustainable socio-economic development of the region. However, geotourism, which is the tool for this development, will be active in these objects on condition that they will also represent the geological and/or geomorphological values.

Geotourism will bring real incomes in a region provided that the local authorities, responsible for exploiting its geotourism potential, will be conscious of the geological and geomorphological resources in the managed region, and based on this knowledge they will lead appropriate local policy. Their activity is not to be underestimated. The research conducted by Meyer (2010) in the municipalities with different tourism potential has clearly demonstrated that the activity of local authorities is always an important element of tourist potential of the area, and supports or initiates the use of tourist resources, regardless of their nature and importance. 


\section{Conclusions}

1. The area of the planned geopark, named "Postglacial land of the Drawa and Dębnica rivers", is characterized by high geodiversity. It has been evaluated in detail in a part of this area, i.e. along the planned "Połczyn Switzerland" geotourist path. Geodiversity is the main element of the geotourism potential of this region.

2. The activity of entities, which are directly and indirectly involved in (geo)tourism, are also important elements of geotourism potential.

3. The results of evaluation indicate that geotourism, which is a tool for sustainable socio-economic development of the region, has a chance to develop in the study area mainly in these geosites, where business activity is conducted. The objects, which tourists will associate with local craft, and with local product that they willingly would make themselves, will bring the highest profits from geotourism. In the area of the planned geopark, on the "Połczyn Switzerland" geotourist path, there are already two such objects, i.e. the Drahim Castle and Pottery Settlement in Sikory.

4. Most of the other studied geosites have a moderate potential for the development of (geo)tourism in the catchment of the Drawa and Dębnica rivers.

5. As almost all the studied geosites are protected by law, there is hope that they will not be destroyed by tourists. Thus, the possibility is ensured that their educational and tourist functions will be continuously performed and the geological sciences will be promoted.

6. The results of evaluation of the geosites occurring in the analysed, hilly part of the Drawskie Lake District, which stretches longitudinally across the planned geopark, suggest that the whole area located between the Drawa and Dębnica rivers is characterized by moderate to high geotourism potential.

7. Due to the fact that education is the main function of geotourism, it seems that the establishment of a geopark in the study area is very expedient. Geotourism will be a valuable alternative to mass tourism and a supplement to spa tourism in the Połczyn-Zdrój health-resort.

\section{Acknowledgments}

Maria Górska-Zabielska is responsible for the concept and writing the article, collecting, analysis and interpretation of data and the final approval of the article for publication. Katarzyna Kamieńska is responsible for collecting data, drawing Fig. 2, 3, 4 and critical review of the article. The authors divide the contribution percentage as follows: Maria Górska-Zabielska - 75\%, Katarzyna Kamieńska - 25\%.

The authors wish to thank three anonymous reviewers and Zbigniew Zwoliński, for their valuable suggestions and corrections. Special thanks go to Małgorzata Gościńska-Kolanko for drawing Fig. 1 and to Maria Wilgat for the English translation of the text. Field work was funded by the Geological Enterprise POLGEOL from Gdańsk.

\section{References}

Alexandrowicz Z., Miśkiewicz K., 2016. Geopark - od idei do realizacji, ze szczególnym uwzględnieniem Polski (Geopark - from the concept to implementation, with special reference to Poland). Chrońmy Przyrodę Ojczysta 72 (4): 243-253.

Bartkowski T., 1972. Strefa marginalna stadiału pomorskiego w aspekcie deglacjacji strefowej (na wybranych przykładach z Pojezierza Drawskiego i Miastkowskiego na Pomorzu) (Marginal zone of the Pomeranian Phase in terms of deglaciation zone (selected examples of Drawskie Lake District and Miastkowskie Lake District in Pomerania). Badania Fizjograficzne nad Polska Zachodnią 25: 7-60.

Bednarek J., 2016. Zamki i warownie. Online: http://www. zamkipolskie.com/staredrawsko/staredrawsko.html (accessed 10 February 2016).

Bojar-Fijałkowski G., 1974. Legendy znad drawskich jezior (Legends from the Drawa Lakes. Koszalińskie Towarzystwo Społeczno-Kulturalne, Koszalin.

Borówka R.K., Cedro B., Duda T., Woziński R., 2008. Obiekty geoturystyczne na wyspie Wolin oraz ocena ich przydatności dla potrzeb turystyki edukacyjnej (Geotouristic objects on the island of Wolin and the assessment of their suitability for educational tourism). In: Dutkowski M. (ed.), Problemy turystyki i rekreacji, Wyd. Oficyna In Plus, Szczecin 1: 101-109.

Bremer F., 1994. Geologische Karte von Mecklenburg-Vorpommern. Übersichtskarte 1:500 000 - Oberfläche. Geologisches Landesamt MV, Schwerin.

Bruschi, V. M., Cendrero, A., 2005. Geosite Evaluation; Can we measure intangible values? Il Quaternario 18 (1): 293306.

Buczek-Kowalik M., Mitura T., Klamar R., 2013. Ecomuseums - a new tourism product on the example of the Hole ecomuseum. Annales UMCS, Sectio B, Geographia, Geologia, Mineralogia et Petrographia 68 (1): 57-68.

Cedro B., Borówka R.K., Duda T., 2008. Ocena walorów geoturystycznych wyspy Bornholm (Assessment of ge- 
otouristic values of Bornholm). In: Dutkowski M. (ed.), Problemy turystyki i rekreacji 1: 111-118.

Coratza, P., \& Giusti, C. (2005). Methodological proposal for the assessment of the scientific quality of geomorphosites. Il Quaternario 18(1): 305-313.

Dmytrowski P., Kicińska A., 2011. Waloryzacja geoturystyczna obiektów przyrody nieożywionej i jej znaczenie w perspektywie rozwoju geoparków (Geotouristic valorization of inanimate objects and its importance in the perspective of geoparks development). Problemy Ekologii Krajobrazu, Kielce 29: 11-20.

Dobracka E., 2009a. Szczegółowa mapa geologiczna Polski 1:50 000, arkusz Połczyn-Zdrój, nr 158 (Detailed geological map of Poland 1:50 000, sheet Połczyn-Zdrój, No. 158). Narodowe Archiwum Geolgiczne PIG-PIB, Warszawa.

Dobracka E., 2009b. Objaśnienia do Szczegółowej mapy geologicznej Polski 1:50 000, arkusz Połczyn-Zdrój, nr 158 (Explanations for the Detailed geological map of Poland 1:50 000, sheet Połczyn-Zdrój, No. 158). Narodowe Archiwum Geolgiczne PIG-PIB, Warszawa.

Dobracka E., Lewandowski J., 2002. Strefa marginalna fazy pomorskiej lobu Parsęty (Pomorze Środkowe) (Marginal zone of the Pomeranian phase of Parsęta Lobe (Middle Pomerania. In: Dobracki R., Lewandowski J., Zieliński T. (eds.), Plejstocen Pomorza Środkowego i strefa marginalna lobu Parsety - IX Konferencja „Stratygrafia Plejstocenu Polski”. PIG Oddz. Pomorski - Szczecin, Uniwersytet Śląski, Wydz. Nauk o Ziemi, Sosnowiec: 109-117.

Dobracki R., 2002a. Punkt widokowy - Spyczyna Góra (Viewpoint - Spyczyna Hill). In: Dobracki R., Lewandowski J., Zieliński T. (eds.), Plejstocen Pomorza Środkowego i strefa marginalna lobu Parsęty - IX Konferencja „Stratygrafia Plejstocenu Polski". PIG Oddz. Pomorski - Szczecin, Uniwersytet Śląski, Wydz. Nauk o Ziemi, Sosnowiec, Field trips guide: 125 .

Dobracki R., 2002b. Wycieczka terenowa - trasa I, 6 września 2002r. (Field trip - route I, $6^{\text {th }}$ Sept. 2002). In: Dobracki R., Lewandowski J., Zieliński T. (eds.), Plejstocen Pomorza Środkowego i strefa marginalna lobu Parsęty - IX Konferencja "Stratygrafia Plejstocenu Polski”. PIG Oddz. Pomorski - Szczecin, Uniwersytet Śląski, Wydz. Nauk o Ziemi, Sosnowiec, Field trips guide: $129-130$.

Dowling R. J., 2013. Global Geotourism - An Emerging Form of Sustainable Tourism. Czech Journal of Tourism 2 (2): 59-79.

DSI [Drawskie Strony Intermetowe], 2016. W powiecie drawskim - znajdź atrakcję: Głaz Tempelburg. Online: http://turystyka.dsi.net.pl/template/miejsca/ czaplinek-ciekawe-miejsca/item/99-g\% C5\%82az-tempelburg.html (accessed: 10 February 2016).

Duda T., Borówka R.K., Cedro B., 2008. Inwentaryzacja obiektów geoturystycznych na obszarze archipelagu Wysp Estońskich (Inventory of the geotouristic objects on the area of Estonian archipelago). In: Dutkowski M. (ed.), Problemy turystyki i rekreacji, Wyd. Oficyna In Plus, 1: 119-129.

Głąbiński Z. (ed.), 2009. Tajemnice krajobrazów Pomorza Zachodniego. Przewodnik dla dociekliwych (Secrets of the landscapes of Western Pomerania. A guide for the curious). Wyd. Forum Turystyki Regionów, Szczecin.

Górska-Zabielska M., 2008. Fennoskandzkie obszary alimentacyjne osadów akumulacji glacjalnej i glacjofluwialnej lobu Odry (Fennoscandian mother regions of glacial and glaciofluvial deposits of the Odra lobe (north-western Poland and north-eastern Germany). Wydawnictwo Naukowe UAM, Poznań 78.

Górska-Zabielska M., 2010: Głazy narzutowe w Wielkopolsce (Erratic boulders in Wielkopolska). Prace i Studia z Geografii i Geologii 18: 1-69.

Górska-Zabielska M., 2013. Lapidarium w Żurawcu na Pojezierzu Drawskim, Pomorze środkowe (Petrographic garden in Żurawiec, the Drawskie Lake District, Middle Pomerania). Przegląd Geograficzny 85 (3): 435-454.

Górska-Zabielska M., Nowicka N., Zawieja J., 2015. Georóżnorodność i walory geoturystyczne Drawieńskiego Parku Narodowego, NW Polska (Geodiversity of the Drawa National Park, NW Poland). Biuletyn Państwowego Instytutu Geologicznego Państwowego Instytutu Badawczego 463: $1-42$.

Górska-Zabielska M., Zabielski R., 2016a. O możliwościach rozwoju geoturystyki w Pruszkowie i okolicy (The possibilities of tourism development in Pruszków and the surrounding area). In: Młynarczyk Z., Zajadacz A., (eds.), Uwarunkowania i plany rozwoju turystyki. Turystyka przyrodnicza i uwarunkowania jej rozwoju. Turystyka i Rekreacja - Studia i Prace 18: 27-39.

Górska-Zabielska M., Zabielski R., 2016b (in press). Walory geoturystyczne miasta na przykładzie Pruszkowa (Geotouristic values of a town on the example of Pruszków). Space - Society - Economy, Łódź.

Gray M., 2004. Geodiversity: Valuing and Conserving Abiotic Nature. Wiley, Chichester.

Gruszka B., Heliasz Z., Lewandowski J., 2002. Stanowisko nr 6 - Lipowa Góra. Środowisko sedymentacji w strefie supraglacjalnej (Site No. 6 - Lipowa Hill. Sedimentological environment in a supraglacial zone). In: Dobracki R., Lewandowski J., Zieliński T. (eds.), Plejstocen Pomorza Środkowego i strefa marginalna lobu Parsęty - IX Konferencja "Stratygrafia Plejstocenu Polski”. PIG Oddz. Pomorski - Szczecin, Uniwersytet Śląski, Wydz. Nauk o Ziemi, Sosnowiec, Field trips guide: 167-171.

Hołubczat E., 2010: Drawieński Park Narodowy 1990-2010 (Drawa National Park 1990-2010). In: Januszewski S. (ed.), Ekomuzeum rzeki Drawy. Wydawca: Drawieński Park Narodowy. Fundacja Otwartego Muzeum Techniki: 13-20.

Kamieńska K., Giemza A., 2013. Inwentaryzacja geostanowisk na obszarze projektowanego Geoparku Polodowcowa Kraina Drawy $i$ Dębnicy (Inventory of geosites on an area of the planned Geopark Postglacial Land of the Drawa and Dębnica Rivers). POLGEOL S.A. Zakład w Gdańsku.

Kamieńska K., Giemza A., 2014. Inwentaryzacja geostanowisk na obszarze projektowanego Geoparku Polodowcowa Kraina Drawy i Dębnicy (Inventory of geosites on an area of the planned Geopark Postglacial Land of the Drawa and Dębnica Rivers). Przegląd Geologiczny 62 (1): 15-21.

Kłysz P., 1992: Osady czwartorzędowe cementacji węglanowej w okolicy Czaplinka na Pojezierzu Drawskim (Quaternary deposits of carbonate cementation at Czaplinek, Drawskie Lake District). Badania Fizjograficzne nad Polską Zachodnia, Ser. A, Geografia Fizyczna 44: 93-101.

Kostrzewski A., 1998. Georóżnorodność rzeźby jako przedmiot badań geomorfologii (Relief geodiversity as an object of geomorphological studies). In: Pękala K. (ed.), Gtówne kierunki badań geomorfologicznych w Polsce. Stan aktualny i perspektywy, IV Zjazd Geomorfologów Polskich, 
Lublin, 3-6.06.2998, Referaty i komunikaty, Wyd. UMCS: 11-16.

Kostrzewski A., 2011. The role of relief geodiversty in geomorphology. Geographia Polonica, 84(Sp. Iss. Pt 2): 69-74.

Kot R., 2006. Problem określenia georóżnorodności na przykładzie fordońskiego odcinka dolnej Wisły. Regionalne Studia Ekologiczno-Krajobrazowe (The problem of determining the geodiversity on the example of Fordon part of the lower Vistula. Regional Studies on Ecology Landscape). Problemy Ekologii Krajobrazu 16: 227-240.

Kot R., Leśniak K., 2006. Ocena georóżnorodności za pomocą miar krajobrazowych - podstawowe trudności metodyczne (Assessment of geodiversity with the help of landscape measurements - basic methodical difficulties). Przeglad Geograficzny 78 (1): 25-45.

Kozarski S., 1986. Skale czasu a rytm zdarzeń geomorfologicznych vistulianu na Niżu Polskim (Time scales and the rhythm of geomorphological events of Vistulian on the Polish Lowlands). Czasopismo Geograficzne 57: 247-270.

Kozarski S., 1988. Time and dynamics of the Last Scandinavian Ice-Sheet retreat from northwestern Poland. Geographia Polonica 55: 91-101.

Kozarski S., 1995. Deglacjacja północno-zachodniej Polski: warunki i transformacja geosystemu ( 20 ka - $10 \mathrm{ka} \mathrm{BP})$ (Deglaciation of the north-western Poland: conditions and geosystem transformation ( 20 ka - $10 \mathrm{ka} \mathrm{BP}))$. IGiPZ PAN, Dokumentacja Geograficzna 1, 82 p.

Kozłowski S., 1997. Prognoza ochrony georóżnorodności w Polsce (Intension to protect the geodiversity in Poland). Przeglad Geologiczny, 5: 489-496.

Kubalíková, L., 2013. Geomorphosite assessment for geotourism purposes. Czech Journal of Tourism 2(2): 80-104.

Liedtke H., 1981. Die nordischen Vereisungen in Mitteleuropa. Forschungen zur deutschen Landeskunde, 204 p.

Marks L. 2011. Quaternary Glaciations in Poland. Developments in Quaternary Science 15: 299-303.

Marks L., 2002. Last Glacial Maximum in Poland. Quaternary Science Reviews 21: 103-110.

Marsz A., 1971. Zmiany linii brzegowej jeziora Komorze (Pojezierze Drawskie) (Changes of the shoreline of Komorze Lake (Drawskie Lake District). Badania Fizjograficzne nad Polska Zachodnia 24: 187-197.

Marsz A., 1973. Niektóre zagadnienia geomorfologii bezpośredniego przedpola zasięgu stadiału pomorskiego na Pojezierzu Drawskim (na przykładzie obrzeżenia rynny marginalnej Drawsko-Pile) (Some issues of geomorphology of the immediate foreground of the ice sheet extent during the Pomeranian phase in the area of the Drawskie Lake District (an example of the margin of the marginal tunel valley of the Drawsko-Pile Lake). Badania Fizjograficzne nad Polska Zachodnia 26: 97-141.

Mazurek M., 2006. Wypływy wód podziemnych w południowej części dorzecza Parsęty (Groundwater outflows in the southern part of the Parsęta catchment). Badania Fizjograficzne nad Polska Zachodnia 57: 101-118.

Mazurek M., Paluszkiewicz Re., Piotrowska I., 2010. Walory turystyczne sieci dolinnej w dorzeczu Parsęty (The tourist attractions of the river network in the Parseta catchment). Krajobraz a turystyka. Prace Komisji Krajobrazu Kulturowego 14: 229-242.

Meyer B., 2010. Aktywność samorządu lokalnego jako element potencjału turystycznego na przykładzie wybranych gmin województwa zachodniopomorskiego (The activity of local self-government as part of the tourism potential based on selected municipalities of West
Pomeranian Province). Zeszyty Naukowe Uniwersytetu Szczecińskiego 590, Ekonomiczne problemy ustug 52: 23-32.

MS [Ministerstwo Środowiska], 2016. Kierunki badań w dziedzinie geologii środowiskowej (na lata 2008-2015). Online: http://www.mos.gov.pl/g2/kategoriaPliki/2009_04/01_geol_srodowiskowa.pdf (accessed 11 November 2016).

Najwer A., Zwoliński Z., 2014a. Semantyka i metodyka oceny georóżnorodności - przegląd i propozycja badawcza (Semantics and geodiversity assessment methods - review and research proposal). Landform Analysis 26: 115-127.

Najwer A., Zwoliński Z., 2014b. The landform geodiversity assessment method - a comparative analysis for Polish and Swiss mountainous landscape. IGU 2014 Book of Abstracts: 1201.

Najwer A., Zwoliński Z., 2015. Geomorphometry-based method of landform assessment for geodiversity. EGU General Assembly 2015 Conference Abstracts 17: 980.

Najwer A., Borysiak J., Gudowicz J., Mazurek M., Zwoliński Z., 2016. Geodiversity and biodiversity of the postglacial landscape (Dębnica river catchment, Poland). Quaestiones Geographicae 35(1): 5-28.

Nita J., 2007. Waloryzacja budowy geologicznej dla potrzeb zachowania georóżnorodności (Valorization of the geological structure to maintain the geodiversity conservation). In: Kistkowski M., Korwel-Lejkowska B. (eds.), Waloryzacja środowiska przyrodniczego w planowaniu przestrzennym, Gdańsk-Warszawa: 111-115.

Panizza, M., 2001. Geomorphosites: concepts, methods and example of geomorphological survey. Chinese Science Bulletin 46-Suppl.: 4-6.

Pereira P., Pereira D., Caetano Alves M.I, 2007. Geomorphosite assessment in Montesinho Natural Park (Portugal). Geographica Helvetica 62(3): 159-168.

Pereira, P., Pereira, D. 2010. Methodological guidelines for geomorphosite assessment. Géomorphologie: relief, processus, environnement 1(3): 215-222.

PIG-PIB [Państwowy Instytut Geologiczny - Państwowy Instytut Badawczy], 2016. Polish Central Register of Geosites. Online: geoportal.pgi.gov.pl/portal/page/portal/ geostanowiska/ (accessed 11 November 2016).

Pralong, J. P., 2005. A method for assessing tourist potential and use of geomorphological sites. Géomorphologie: relief, processus, environnement 1(3): 189-196.

Radwanek-Bąk B., Laskowicz I., 2012. Ocena georóżnorodności jako metoda określania potencjału geoturystycznego obszaru (Valorization of geodiversity as a method of geotourism potential assesment). Annales UMCS, Sectio B 67 (2): 77-95.

Reynard E., 2004. Protecting stones: conservation of erratic blocks in Switzerland. In: Přikryl R. (ed.), Dimension Stone. New Perspectives for a Traditional Building Material. Prague, 14-17.06.2004, Leiden, A.A.Balkema Publishers: 3-7.

Reynard E., 2005. Geomorphological sites, public policies and property rights. Conceptualization and examples from Switzerland. Il Quaternario 18(1): 321-330.

Reynard E., Fontana G., Kozlik L., Scapozza C., 2007. A method for assessing «scientific» and «additional values» of geomorphosites. Geographica Helvetica 62(3): 148-158.

Rinterknecht V. R., Marks L., Piotrowski J. A., Raisbeck G. M., Yiou F., Brook E. J., Clark P. U., 2005. Cosmogenic ${ }^{10} \mathrm{Be}$ ages on the Pomeranian Moraine, Poland. Boreas 34: 186-191. 
Serrano Cañadas, E., \& Gonzáles-Trueba, J. J., 2005. Assessment of geomorphosites in natural protected areas: the Picos de Europa National Park (Spain). Géomorphologie: relief, processus, environnement 1(3): 197-208.

Sołowiej D., 1992. Podstawy metodyki oceny środowiska przyrodniczego człowieka (Basics of methodology to evaluate the natural environment of man). Wydawnictwo Naukowe UAM, Poznań.

Warowna J., Zgłobicki W., Kołodyńska-Gawrysiak R., Migoń P., Kiebała A., 2013. Dziedzictwo geomorfologiczne Polski jako atrakcja turystyczna (Geomorphological heritage of Poland as touristic attractions). Studia i Materiaty Centrum Edukacji Przyrodniczo-Leśnej w Rogowie 15(37/4): 328-334.

Zaręba D., 2010: Ekoturystyka. Wyzwania i nadzieje (Ecotourism. Challenges and hopes). Wydawnictwo Naukowe PWN, Warszawa.

Zbucki Ł., 2012. Aktywność geoturystyczna mieszkańców Niziny Południowopodlaskiej (The geotourist activity of inhabitants of the Southern Podlasie Lowland). Annales UMCS, Sectio B 67(2): 129-136.

Zgłobicki W., Baran-Zgłobicka B., 2013. Geomorphological Heritage as a Tourist Attraction. A Case Study in Lubelskie Province, SE Poland. Geoheritage 5: 137-149.

Zgłobicki W., Brzezińska-Wójcik T., Gawrysiak L., Harasimiuk M., 2007. Geomorphosites of Lublin region as a tool for the development of geotourism. In: Harasimiuk M., Brzezińska-Wójcik T., Dobrowolski R., Mroczek P., Warowna J. (eds.), Geological structure of Lublin region and problems of lithosphere conservation. Maria Curie-Skłodowska University, Lublin: 271-277.

Zouros N., 2005. Assessment, protection, and promotion of geomorphological and geological sites in the Aegean area, Greece. Géomorphologie: felief, processus, enivronnement 1(3): 227-234.

Zouros N., 2007. Geomorphosite assessment and management in protected areas of Greece. Case study of the Lesvos Island - coastal geomorphosites. Geographica Helvetica 62(3): 169-180.

Zwoliński Z., 2004. Geodiversity. In: Goudie A. S. (ed.), Encyclopedia of Geomorphology, vol. 1, Routledge: 417-418.

Zwoliński Z., 2009. The routine of landform geodiversity map design for the Polish Carpathian Mts. In: Rojan E, Łajczak A.(eds.), Geoecology of the Euroasiatic Alpids. Landform Analysis 11: 79-87.

Zwoliński Z., 2010. Aspekty turystyczne georóżnorodności rzeźby Karpat (Touristic aspects of geodiversity of the Carpathians Mts.). Prace Komisji Krajobrazu Kulturowego PTG 14: 316-327.

Zwoliński Z., Stachowiak J., 2012. Geodiversity map of the Tatra National Park for geotourism. Quaestiones Geographicae 31(1): 99-107. 